\title{
Can chlorine dioxide prevent the spreading of coronavirus or other viral infections? Medical hypotheses
}

\author{
K. KÁLY-KULLAI ${ }^{1}$, M. WITTMANN ${ }^{1}$, Z. NOSZTICZIUS $^{1}$ and \\ LÁSZLÓ ROSIVALL ${ }^{2 *}$
}

\footnotetext{
${ }^{1}$ Department of Physics, Group of Chemical Physics, Budapest University of Technology and Economics, Budapest, Hungary

${ }^{2}$ Institute of Translational Medicine and International Nephrology Research and Training Center, Semmelweis University, Budapest, Hungary
}

Published online: March 31, 2020

(c) 2020 The Author(s)

\section{INTRODUCTION}

\section{Motivation}

Viruses have caused many epidemics throughout human history. The novel coronavirus [10] is just the latest example. A new viral outbreak can be unpredictable, and development of specific defense tools and countermeasures against the new virus remains time-consuming even in today's era of modern medical science and technology. In the lack of effective and specific medication or vaccination, it would be desirable to have a nonspecific protocol or substance to render the virus inactive, a substance/protocol, which could be applied whenever a new viral outbreak occurs. This is especially important in cases when the emerging new virus is as infectious as SARS-CoV-2 [4].

\section{Aim and structure of the present communication}

In this editorial, we propose to consider the possibility of developing and implementing antiviral protocols by applying high purity aqueous chlorine dioxide $\left(\mathrm{ClO}_{2}\right)$ solutions. The aim of this proposal is to initiate research that could lead to the introduction of practical and effective antiviral protocols. To this end, we first discuss some important properties of the $\mathrm{ClO}_{2}$ molecule, which make it an advantageous antiviral agent, then some earlier results of $\mathrm{ClO}_{2}$ gas application

\footnotetext{
* Corresponding author: Prof. emer. Laszlo Rosivall, MD, PHD, DSc, FERA, FAPS, Institute of Translational Medicine, International Nephrology Research and Training Center, Semmelweis University, Budapest, Nagyvárad tér 4., H-1089, Hungary. Tel/Fax: 36-1-2100-100, E-mail: rosivall.laszlo@med.semmelweis-univ.hu
} 
against viruses will be reviewed. Finally, we hypothesize on methods to control the spread of viral infections using aqueous $\mathrm{ClO}_{2}$ solutions.

\section{PREVIOUS EXPERIENCE AND BACKGROUND OF USING $\mathrm{CIO}_{2}$ AS AN ANTIVIRAL AGENT}

\section{Inactivating viruses with $\mathrm{ClO}_{2}$ in aqueous phase}

To our present knowledge, an aqueous solution of $\mathrm{ClO}_{2}$ is able to inactivate all types of viruses. Disinfectants (in water phase) are compared by their CT values, which is the concentration (measured in $\mathrm{mg} / \mathrm{L}$ ) multiplied by the contact time (measured in minute). In $\mathrm{CT}$ tables, $\mathrm{ClO}_{2}$ is indicated for viruses in general, without mentioning any exemptions. For example, according to [6], a CT value of $8.4 \mathrm{mg} \times \mathrm{min} / \mathrm{L}$ is needed to achieve a four-orders-of-magnitude (" $4 \mathrm{log}$ " or "99.99\%") inactivation of viruses in an aqueous medium at $25^{\circ} \mathrm{C}$.

\section{Chemical mechanism of virus inactivation: reaction of $\mathrm{ClO}_{2}$ with amino acid residues}

In 1986, Noss et al. [19] proved that the inactivation of bacterial virus $\mathrm{f} 2$ by $\mathrm{ClO}_{2}$ was due to its reactions with the viral capsid proteins, and almost no inactivation of the infectious viral RNA occurred [8] when that was treated with $\mathrm{ClO}_{2}$ separately. They found [19], however, that three discrete chemical moieties in the viral protein, namely the cysteine, tyrosine, and tryptophan amino acid residues were able to react with $\mathrm{ClO}_{2}$ rapidly. In 1987, Tan et al. [28] tested the reactivity of $\mathrm{ClO}_{2}$ on 21 free amino acids. $\mathrm{ClO}_{2}$ reacted only with six amino acids dissolved in 0.1 $\mathrm{M}$ sodium phosphate buffer, $\mathrm{pH}$ 6.0. The reaction with cysteine, tryptophan, and tyrosine was too rapid to be followed by their technique. Three further amino acids (histidine, hydroxyproline, and proline) reacted with $\mathrm{ClO}_{2}$ much more slowly, at a measurable rate.

The reactivity of the three fast-reacting amino acids (cysteine [12], tyrosine [17], and tryptophan [27]) was studied in Margerum's laboratory between 2005 and 2008. They found that cysteine had the highest reactivity among these amino acids. From their experimental data they calculated second order-rate constants (at pH 7.0, $25{ }^{\circ} \mathrm{C}$ and $1 \mathrm{M}$ ionic strength) and obtained the following sequence: cysteine $6.9 \times 10^{6} \mathrm{M}^{-1} \mathrm{~s}^{-1}>$ tyrosine $1.3 \times 10^{5} \mathrm{M}^{-1} \mathrm{~s}^{-1}>$ tryptophan $3.4 \times 10^{4} \mathrm{M}^{-1} \mathrm{~s}^{-1}>$ guanosine $5^{\prime}$-monophosphate $4.5 \times 10^{2} \mathrm{M}^{-1} \mathrm{~s}^{-1}$. (They studied guanosine $5^{\prime}$-monophosphate [18] as a model compound for guanine in nucleic acids. Data presented here are taken from Table 3 of ref. [18]).

In 2007, Ogata [22] found that the antimicrobial activity of $\mathrm{ClO}_{2}$ is based on denaturation of certain proteins, which is primarily due to the oxidative modification of the tryptophan and tyrosine residues of the two model proteins (bovine serum albumin and glucose-6-phosphate dehydrogenase) used in his experiments. In 2012, it was again Ogata who showed [23] that the inactivation of influenza virus by $\mathrm{ClO}_{2}$ was caused by oxidation of a tryptophan residue (W153) in hemagglutinin (a spike protein of the virus), thereby abolishing its receptor-binding ability.

In this context it is interesting to remark that the spike protein of the new coronavirus SARS_CoV-2 contains 54 tyrosine, 12 tryptophan, and 40 cysteine residues [29]. If we assume that in an aqueous solution all of these residues are able to react with $\mathrm{ClO}_{2}$ just like the free amino acids, then the inactivation of the viruses can be extremely rapid even in a very dilute (e.g., in a $0.1 \mathrm{mg} / \mathrm{L}$ ) $\mathrm{ClO}_{2}$ solution. 


\section{$\mathrm{ClO}_{2}$ is a water soluble gas}

Although chlorinedioxide in itself is a gas, it is highly soluble in water. When both air and water are present, $\mathrm{ClO}_{2}$ is distributed between the two phases in an equilibrium ratio determined by the temperature. This distribution coefficient of $\mathrm{ClO}_{2}$ was determined by Ishi [11] in 1958. The distribution coefficient, $\gamma=\left[\mathrm{ClO}_{2}\right]_{\mathrm{G}} /\left[\mathrm{ClO}_{2}\right]_{\mathrm{L}}$ gives the ratio of the concentrations expressed in the same units in the gas and the aqueous phases (e.g., g/L) and changes as a function of the temperature. For example, at $20{ }^{\circ} \mathrm{C} \gamma=0.0316$, indicating that in equilibrium $1 \mathrm{~cm}^{3}$ aqueous phase contains $(0.0316)^{-1}=31.6$ times more $\mathrm{ClO}_{2}$ molecules than $1 \mathrm{~cm}^{3}$ gas phase.

In practice, the concentrations in the two phases are usually given in ppm. However, these dimensionless numbers are defined in a different way in the gas and liquid phases as ppm $(\mathrm{V} / \mathrm{V})$ and ppm $(\mathrm{m} / \mathrm{m})$, respectively. Therefore, for practical purposes, we need a distribution coefficient, which gives the ratio between these concentrations. Straightforward calculation yields that the distribution coefficient in terms of ppm is 357 times the distribution coefficient in terms of (g/L), so at $20{ }^{\circ} \mathrm{C} \gamma_{\mathrm{ppm}}=11.3$. Thus, the following formula can be used to calculate the $\mathrm{ClO}_{2}$ concentration of the gas phase being in equilibrium with a $\mathrm{ClO}_{2}$ solution at $20{ }^{\circ} \mathrm{C}$ :

$$
\left[\mathrm{ClO}_{2}\right]_{\mathrm{gas}} \text { in } \operatorname{ppm}(\mathrm{V} / \mathrm{V})=11.3 \times\left[\mathrm{ClO}_{2}\right]_{\mathrm{aq}} \text { in } \operatorname{ppm}(\mathrm{m} / \mathrm{m})
$$

\section{Inactivating viruses with $\mathrm{ClO}_{2}$ in gas phase}

The virus-inactivating reactions (the reactions of $\mathrm{ClO}_{2}$ with the three amino acids) take place in an aqueous medium; consequently, $\mathrm{ClO}_{2}$ can inactivate microbes in their wet state only. Therefore, $\mathrm{ClO}_{2}$ gas that is moisturized can be an ideal agent against viruses both in their wet and dry states. Viruses that are carried by water droplets could be easily inactivated even by $\mathrm{ClO}_{2}$ gas owing to the high solubility of $\mathrm{ClO}_{2}$ in water [11]. A dry $\mathrm{ClO}_{2}$ gas would be inappropriate as the water content of the aqueous droplet could evaporate, and in the absence of aqueous medium the reactions of $\mathrm{ClO}_{2}$ slow down extremely. Indeed, Morino et al. [16] reported that when applying a low concentration of $\mathrm{ClO}_{2}$ in the gas phase against FCV in dry state, atmospheric moisture - at least a $75-85 \%$ relative humidity - is indispensable to inactivate viruses. The advantage of using a moisturized $\mathrm{ClO}_{2}$ gas is that its water content is also able to wet viruses in dry environment. Most viruses are found on hard surfaces indoor, but a small fraction of viruses are "airborn", attached to dust particles, which can also carry a single microbe or an aggregate of microbes. Therefore, it is a prerequisite of an effective disinfection that all microbes in all parts of the room should be wet and should be in contact with $\mathrm{ClO}_{2}$. If enough aqueous $\mathrm{ClO}_{2}$ solution is sprayed into the room, the droplets will saturate the atmosphere with water vapor everywhere, moreover, the atmosphere will also contain gaseous $\mathrm{ClO}_{2}$ everywhere. The great advantage of this method is that $\mathrm{H}_{2} \mathrm{O}$ and $\mathrm{ClO}_{2}$ molecules of the gas phase can reach the microbes in every small corner of the room. Finely dispersed water droplets containing dissolved $\mathrm{ClO}_{2}$ can create an advantageous environment to maintain such conditions for a longer time.

This method using high $\mathrm{ClO}_{2}$ concentration allows fast disinfection of rooms when people are not present, e.g., intensive care units, buildings used as quarantine, or public transport vehicles. However, the application of $\mathrm{ClO}_{2}$ gas is limited when people are present, as it is harmful for humans and animals above certain concentrations. The US Occupational Safety and Health Administration (OSHA) limits the concentration of $\mathrm{ClO}_{2}$ gas allowed in workplace air to 
$0.1 \mathrm{ppm}(\mathrm{V} / \mathrm{V})$ time-weighted average (TWA) for an 8-h exposure, and to a temporarily higher $0.3 \mathrm{ppm}$ Short-Term Exposure Limit (STEL) only for a 15-min period [30].

\section{Previous research on preventing viral infections with gaseous $\mathrm{ClO}_{2}$}

Ogata [21] realized first that $\mathrm{ClO}_{2}$ is able to inactivate viruses even under the $0.1 \mathrm{ppm}$ (OSHA TWA) limit that is in concentrations which are not harmful to humans. In 2008, Ogata and Shibata [25] demonstrated that infection of mice with influenza A virus applied in an aerosol can be prevented by $\mathrm{ClO}_{2}$ gas present at $0.03 \mathrm{ppm}$ concentration in the air, which is only $30 \%$ of the permissible TWA exposure level for humans at a workplace. They concluded that " $\mathrm{ClO}_{2}$ gas could, therefore, be useful as a preventive tool against influenza in places of human activity without necessitating evacuation." They have even made attempts to decrease the incidence of flue infections among schoolchildren by applying low concentrations of $\mathrm{ClO}_{2}$ gas in a classroom [24].

In spite of these promising early results we are not aware of any wider-scale application of this method in the last decade. There are two problems which could hinder the widespread adoption of this method:

1. With the technique applied by the above-cited authors it is not an easy task to achieve and maintain a very low $\mathrm{ClO}_{2}$ concentration in a large space and for a long time, which is a prerequisite of achieving a satisfactory level of virus inactivation.

2. It is not understood why low $\mathrm{ClO}_{2}$ levels are not harmful to humans or animals and still effective against viruses.

\section{Size selective effect of $\mathrm{ClO}_{2}$}

Although cysteine, tyrosine, and tryptophan residues can also be found in human tissues, $\mathrm{ClO}_{2}$ is much less toxic for humans or animals than for microbes (bacteria, fungi, and viruses). Noszticzius et al. [20] found that the main reason for this selectivity between humans and microbes is based not on their different biochemistries but on their different sizes. Based on experiments and calculations using a reaction-diffusion model Noszticzius et al. [20] found that the killing time of a living organism is proportional to the square of its characteristic size (e.g., its diameter), thus small ones will be killed extremely fast. Their calculations indicated that a bacterium $1 \mu \mathrm{m}$ in diameter would be killed in a $300 \mathrm{mg} / \mathrm{L} \mathrm{ClO}_{2}$ solution within $3 \mathrm{~ms}$, and even in a much more dilute, $0.25 \mathrm{mg} / \mathrm{L} \mathrm{ClO}_{2}$ solution it would be eliminated in only $3.6 \mathrm{~s}$. During this time, $\mathrm{ClO}_{2}$ reaches all parts of the cell and kills it by destroying its cysteine-, tyrosine-, and tryptophan-containing proteins, which are essential for life processes.

\section{The protective role of glutathione against $\mathrm{ClO}_{2}$ oxidation in a living cell}

According to Ison et al. [12] glutathione reacts with $\mathrm{ClO}_{2}$ at a rate, which is even higher than the rate of the very fast $\mathrm{ClO}_{2}-$ cysteine reaction. When $\mathrm{ClO}_{2}$ contacts a living cell containing glutathione, at first the $\mathrm{ClO}_{2}$ concentration remains very low even at the point of entry into the cell due to this rapid reaction. As a small molecule, glutathione can also diffuse rapidly to the point of entry from other parts of the cell consuming most of the $\mathrm{ClO}_{2}$ there, and preventing it from reaching the cysteine, tyrosine, and tryptophan residues of the proteins in the bulk of the cytoplasm. Consequently, the initial low $\mathrm{ClO}_{2}$ concentration cannot make too much harm. 
However, continuous $\mathrm{ClO}_{2}$ entry can finally exhaust the cell's glutathione (and other antioxidant) capacity even if the cell produces such antioxidants continuously. At this point, $\mathrm{ClO}_{2}$ can enter into the previously protected zones of the cell and react with the reactive amino acid residues, causing denaturation of the affected proteins and ultimately cell death.

The effect of glutathione and other small antioxidant molecules present in living cells was not taken into account in the theoretical calculations of Noszticzius et al. [20]. Their experiments were done on a non-living and washed animal membrane, where membrane-fixed reactive proteins were present, but glutathione and other small molecules were absent. A living cell, however, continuously produces these antioxidants, thus their role cannot be neglected. Indeed, looking at the experimentally measured disinfection dynamics of a $0.25 \mathrm{mg} / \mathrm{L} \mathrm{ClO}_{2}$ solution against Escherichia coli bacteria [2] we can see a disinfection rate, which is surprisingly fast but still about one order of magnitude slower than the theoretical estimate. It is reasonable to assume that the delaying effect of these small reducing molecules is responsible for that deviation.

\section{Protection of human tissues against the oxidative effect of $\mathrm{ClO}_{2}$}

Human cells also contain glutathione in $\mathrm{mM}$ concentrations, as well as other antioxidants like vitamin $\mathrm{C}$ and $\mathrm{E}$, which work together with glutathione to reduce $\mathrm{ClO}_{2}$ [7]. As a human cell is much larger than a bacterium, consequently its glutathione reserve and glutathione production potential are also greater, so even an isolated human cell can survive much longer in a $\mathrm{ClO}_{2}$ environment than a planktonic bacterium. Considering that human cells are not isolated but form tissues, their glutathione stock may be many orders of magnitude greater than that of a planktonic bacterium. Additionally, in multicellular organisms circulation transports antioxidants continuously to the cells of the tissue affected by a $\mathrm{ClO}_{2}$ attack, helping them to survive. This strengthens the size-selectivity effect, and explains the surprising observation [15] that $\mathrm{ClO}_{2}$ solutions that are able to kill planktonic bacteria in a fraction of a second may be consumed, because they are safe for humans to drink in a small amount (e.g., drinking $1 \mathrm{~L}$ of 24 $\mathrm{mg} / \mathrm{L} \mathrm{ClO}_{2}$ solution in two portions on a single day caused no observable effects in humans [15]).

\section{The effect of $\mathrm{ClO}_{2}$ on the lung}

While human tissues are not very sensitive to $\mathrm{ClO}_{2}$ in general, lungs should be considered differently. This is because the interalveolar septum separating the airspace of an alveolus from the blood stream of a capillary lumen is very thin. That diffusion barrier in the human lung is a mere $2 \mu \mathrm{m}$ thick [1] in order to facilitate an efficient diffusional exchange of oxygen and carbon dioxide between the air and blood. The alveolus is covered by a thin layer of lining fluid called epithelial lung lining fluid (ELF) or hypophase. The ELF is only $0.2 \mu \mathrm{m}$ thick in rat alveoli [1, 13]. It contains glutathione [3] and other antioxidants such as ascorbic and uric acids [5]. It is remarkable, that the ascorbic acid concentration is 2.5 times, and the glutathione concentration is more than 100 times higher in the ELF than in the plasma. The normal function of these nonenzymatic antioxidants in the ELF is to protect the epithelial cells from reactive oxygen species (ROS) like superoxide radicals or hydrogen peroxide, which are toxic products of the metabolism. They can also defend the lung against other toxic gases such as ozone $\left(\mathrm{O}_{3}\right)$, nitrogen dioxide $\left(\mathrm{NO}_{2}\right)$ or $\mathrm{ClO}_{2}$. However, high amounts of $\mathrm{ClO}_{2}$ can consume all reducing agents in the 
$\mathrm{ELF}$, at which point $\mathrm{ClO}_{2}$ starts to react with the epithelial cells causing a continuously growing damage to these cells. It is known that higher concentrations of $\mathrm{ClO}_{2}$ gas can be lethal. However, it is reasonable to assume that the effect of $\mathrm{ClO}_{2}$ on the lung depends not only on its concentration in the gas phase but also on the contact time. Thus, when considering the impact of $\mathrm{ClO}_{2}$ on the lung, it would be logical to regard the CT (concentration) $\times$ (contact time) product in a similar way as in the case of the microbes.

\section{Estimating the inactivation time of viruses}

In the case of viruses, the inactivation mechanism differs from that of bacteria or other cells. It is feasible to assume that the inactivation time of a virus is probably much shorter than the inactivation time of a bacterium under the same conditions $\left(\mathrm{ClO}_{2}\right.$ concentration, temperature, etc.). The following arguments support this assumption:

1. Viruses are about one order of magnitude smaller than bacteria e.g., the diameter of SARS_CoV-2 is about $120 \mathrm{~nm}$ [9]. The killing time of a virus as introduced in [20] would be 1-2 orders of magnitude shorter than that of a bacterium, i.e., the diffusion-controlled reaction with $\mathrm{ClO}_{2}$ would happen on a shorter time scale in the entire volume of the virus.

2. It is not necessary for $\mathrm{ClO}_{2}$ gas to penetrate the virus in order to inactivate it. It is enough if $\mathrm{ClO}_{2}$ reacts with one or some of the cysteine, tyrosine, and tryptophan amino acid residues of the spike, which are located on the surface of the virus. This means that the theoretical approach of ref. [20] overestimates the inactivation time of viruses. On the one hand, because diffusion is extremely fast over a $0.1 \mu \mathrm{m}$ length scale, thus probably it is not limiting the rate of the reactions. On the other hand, $\mathrm{ClO}_{2}$ can reach a large part of the reactive amino acid residues of the spike without permeating through the protein envelope of the virus.

3. Viruses do not contain protective small molecular thiols like glutathione or other small molecular protective metabolic products, because viruses have no metabolism. In this respect viruses should be much more vulnerable than bacteria to an attack by $\mathrm{ClO}_{2}$.

These facts all suggest that once $\mathrm{ClO}_{2}$ contacts the surface of a virus, its inactivation is quick. However, a virus ready to infect a cell is typically in aqueous phase, e.g., in a fluid droplet, or in the epithelial lining fluid covering the mucous membranes. The size of these aqueous phases is much larger than that of the virus. Therefore, in such cases, the rate-limiting step probably is the diffusion of $\mathrm{ClO}_{2}$ in the water and the reaction with other substances. The time required to inactivate the virus itself would be short compared to the time needed to transport enough $\mathrm{ClO}_{2}$ molecules to the virus.

\section{SUGGESTIONS FOR PREVENTING THE SPREAD OF VIRAL INFECTIONS USING $\mathrm{ClO}_{2}$}

Based on the previous arguments, some propositions will now be put forward on how aqueous $\mathrm{ClO}_{2}$ solutions could be applied for global and local (personal) disinfection purposes. Many of these propositions are based on hypotheses, and therefore can only be applied after careful research. It is a goal of the present work to initiate research to check these hypotheses and proposals experimentally, which could lead to new applications of high-purity $\mathrm{ClO}_{2}$ solutions against viral or other infections. These ideas might be further matured in time, but due to the threat of a global pandemic, we have chosen to move fast. 


\section{Global prevention}

Disinfection of air spaces, hard surfaces, and persons simultaneously with aqueous $\mathrm{ClO}_{2}$ solutions. What we are proposing here is basically the same idea what has been already proposed by Ogata et al. [21, 24, 25]: it is possible to create $\mathrm{ClO}_{2}$ atmospheres which can be safe for humans but at the same time harmful for microbes. There are differences, however, between their proposals and ours. Ogata's group regarded the $\mathrm{ClO}_{2}$ concentration $(\mathrm{C})$ of the atmosphere as the sole important parameter of the treatment. They proposed to apply a $\mathrm{ClO}_{2}$ concentration below the $0.1 \mathrm{ppm}(\mathrm{V} / \mathrm{V})$ OSHA limit, for a time that is necessary to inactivate the microbes. With such a method, however, the necessary contact time $(\mathrm{T})$ can be very long. Here we suggest regarding the CT product as the parameter of disinfection. In this way it is possible to apply $\mathrm{ClO}_{2}$ concentrations above the OSHA limit but for a limited time only. The advantage of this method is that as higher $\mathrm{C}$ values are applied, the necessary contact times can be much shorter. The idea will be illustrated by a numerical example below.

Another important difference is that Ogata's method focuses mostly on the role of the $\mathrm{ClO}_{2}$ gas, whereas we emphasize the importance of the simultaneous usage of $\mathrm{ClO}_{2}$ and $\mathrm{H}_{2} \mathrm{O}$ gases, as confirmed by the observations of Morino et al. [16]. For this purpose, we suggest a new way of creating a $\mathrm{ClO}_{2}$ atmosphere: to apply aqueous $\mathrm{ClO}_{2}$ solutions which can establish equilibrium $\mathrm{ClO}_{2}$ and $\mathrm{H}_{2} \mathrm{O}$ concentrations in the atmosphere, when these are sprayed into the air. Aqueous solutions are also easier to handle than to maintain stable and very low $\mathrm{ClO}_{2}$ levels in continuous gas streams.

It is advisable to apply high-purity $\mathrm{ClO}_{2}$ solutions for spraying to avoid any unwanted side effects to the persons or the surfaces treated. High-purity $\mathrm{ClO}_{2}$ solutions evaporate without any residue or trace.

An illustrative numerical example. Let us assume that we want to disinfect a closed space by spraying some aqueous stock $\mathrm{ClO}_{2}$ solution into it. The equilibrium $\mathrm{ClO}_{2}$ concentration $c_{\text {air }}$ in the gas and $c_{w, e}$ in the liquid phase can be calculated from the vapor-liquid equilibrium distribution measured by Ishi [11]:

$$
\gamma=\frac{c_{\mathrm{air}}}{c_{w, e}}
$$

and from the component balance for $\mathrm{ClO}_{2}$ :

$$
V_{w} \cdot c_{w 0}=V_{w} \cdot c_{w, e}+V_{\text {air }} \cdot c_{\text {air }}
$$

where $V_{\text {air }}$ is the volume to be disinfected, $V_{w}$ is the volume of the $\mathrm{ClO}_{2}$ stock solution, and $c_{w 0}$ is its $\mathrm{ClO}_{2}$ concentration.

With the help of the above two equations $c_{w, e}$ can be calculated as

$$
c_{w, e}=\frac{c_{w 0}}{1+\gamma \cdot \frac{V_{\text {air }}}{V_{w}}}
$$

Suppose we apply $V_{w}=20 \mathrm{~mL}$ of $c_{w 0}=40 \mathrm{ppm}(\mathrm{m} / \mathrm{m})$ aqueous stock $\mathrm{ClO}_{2}$ solution in a $V_{\text {air }}=1 \mathrm{~m}^{3}$ closed space.

At $20{ }^{\circ} \mathrm{C}$ the value of the distribution coefficient is $\gamma=0.0316$ (data of Ishi [11]) when all concentrations are given in the same units (e.g., in $\mathrm{mg} / \mathrm{L}$ ), and it is $\gamma_{\mathrm{ppm}}=11.3$ (see section $\mathrm{ClO}_{2}$ 
is a water soluble gas) when ppm $(\mathrm{m} / \mathrm{m})$ and $\mathrm{ppm}(\mathrm{V} / \mathrm{V})$ are used in the aqueous and gaseous phases, respectively. Substituting our data the results are

$$
\begin{gathered}
c_{w, e}=0.025 \mathrm{ppm}(\mathrm{m} / \mathrm{m}), \\
c_{\mathrm{air}}=\gamma_{\mathrm{ppm}} c_{w, e}=0.29 \mathrm{ppm}(\mathrm{V} / \mathrm{V})
\end{gathered}
$$

This result is just below the OSHA STEL (Short Term Exposition Limit) value which is 0.30 ppm $(\mathrm{V} / \mathrm{V})$ for $15 \mathrm{~min}$. According to OSHA, STEL is the acceptable average exposure over a short period of time - usually $15 \mathrm{~min} \mathrm{-} \mathrm{as} \mathrm{long} \mathrm{as} \mathrm{the} \mathrm{time-weighted} \mathrm{average} \mathrm{(TWA)} \mathrm{is} \mathrm{not}$ exceeded. If a person is exposed to $0.30 \mathrm{ppm}$ for $15 \mathrm{~min}$, and right after that he or she stays in a $\mathrm{ClO}_{2}$-free atmosphere for $30 \mathrm{~min}$, then the TWA value for this whole $45 \mathrm{~min}$ period is just the acceptable $0.10 \mathrm{ppm}$. All this means that an exposure of a person to a $0.30 \mathrm{ppm} \mathrm{ClO}_{2}$ atmosphere for $15 \mathrm{~min}$ on a single occasion, or even applying that treatment periodically with $30 \mathrm{~min}$ pauses within an $8 \mathrm{~h}$ period, should not cause any health problems.

\section{Questions and remarks.}

1. It is a major question, whether or not a 15 -min stay in a $0.29 \mathrm{ppm}(\mathrm{V} / \mathrm{V}) \mathrm{ClO}_{2}$ atmosphere is enough to inactivate the viruses present? Regarding the wet atmosphere we can assume that the viruses are also wet, or even that they can be found in small water droplets containing $0.025 \mathrm{ppm}(\mathrm{m} / \mathrm{m}) \mathrm{ClO}_{2}$. We have no direct data for the inactivating time of viruses in such a solution, but we have an estimated $15 \pm 5 \mathrm{~s}$ killing time value for an $E$. coli bacterium in a $0.25 \mathrm{ppm}(\mathrm{m} / \mathrm{m}) \mathrm{ClO}_{2}$ solution [2]. It is reasonable to assume that the killing time would be 10 times longer in a 10 times more dilute solution, i.e., $150 \mathrm{~s}=2.5 \mathrm{~min}$. As viruses are probably inactivated faster than bacteria, and $15 \mathrm{~min}$ is six times longer than the estimated 2.5 min for $E$. coli, such a method can be successful, at least in theory.

2. To test such a method, we suggest constructing special disinfecting rooms with larger volume. Starting such experiments would be highly desirable, because this method could be an effective nonspecific defense against all types of viruses and could help to contain viral outbreaks.

\section{Local prevention. Personal disinfection techniques against viral infections}

Disinfection of the mouth and the upper respiratory track with gargling. The current epidemic coronavirus is known to be present in the mouth and both in the upper and lower respiratory tract, but causes severe infections only in the lower respiratory tract, especially in the lung. The incubation period of the disease is several days, but the virus can often be detected in samples taken from the upper respiratory tract a few days before symptoms appear. As discussed in a previous chapter, chlorine dioxide will certainly inactivate the virus. With gargling, the upper respiratory tract is accessible except for the nasal cavity, but that is also accessible using e.g. nose drops or impregnated tampons. These parts can be disinfected by rinsing them regularly with high-purity chlorine dioxide solutions available commercially [31], thus the number of the viruses can be significantly reduced in the mouth and in the upper respiratory tract. We cannot be sure that such a treatment would be enough to prevent the development of the illness, as viruses living in other parts of the body can survive. However, inactivating part of the viruses with such a treatment surely helps the immune system to fight against the disease. In this respect, it is interesting to remark that 
Japanese researchers have proven [26] that regular gargling with drinking water has reduced the incidence of upper respiratory tract infections to a statistically significant extent. The effect was explained by the fact that the drinking water used in the experiments contained $0.5 \mathrm{mg} / \mathrm{L}$ of chlorine, which was used to disinfect the water. We remark here, that in certain places chlorine dioxide is applied for the disinfection of drinking water instead of chlorine.

Disinfection of the lower respiratory track. The first problem is how $\mathrm{ClO}_{2}$ can be safely introduced into the lower respiratory tract. For this purpose any inhalation technique could be applied using aerosols of water droplets containing $\mathrm{ClO}_{2}$ [14].

The second and more important problem is how much $\mathrm{ClO}_{2}$ can be inhaled without damaging the lung? It would be helpful to know the dose of $\mathrm{ClO}_{2}$ that is not yet harmful for the lung. To our knowledge such direct data are not available in the literature, but can be calculated from other data. The starting point for such a calculation is the OSHA STEL value [30], according to which $0.30 \mathrm{ppm} \mathrm{ClO}_{2}$ in the workplace atmosphere is tolerable for a $15 \mathrm{~min}$ period without any damage. The volume of air inhaled by a worker during $15 \mathrm{~min}$ is 15 times the so-called "minute volume ventilation" [32]. According to Table 3 of ref. [32], during light activities e.g., when sitting in a car the minute volume is around $12 \mathrm{~L}$, thus the total inhaled air is about $180 \mathrm{~L}$. In the case of $0.30 \mathrm{ppm}$ concentration the total inhaled amount of $\mathrm{ClO}_{2}$ is $54 \mu \mathrm{L}$, which is (at $20^{\circ} \mathrm{C}$ ) $2.25 \mu \mathrm{mol} \approx 0.15 \mathrm{mg}$ $\mathrm{ClO}_{2}$. Assuming a more vigorous activity it can be two times more, $0.30 \mathrm{mg}$.

This rough calculation indicates that approximately this is the amount of $\mathrm{ClO}_{2}$, which can be tolerated by the lung. The OSHA limit probably applied high safety factors, thus the real limit should be higher.

We suggest that animal experiments should be performed to obtain experimental values for the pulmonary toxicity of $\mathrm{ClO}_{2}$. Furthermore, it would be important to check in additional animal experiments, whether $\mathrm{ClO}_{2}$ applied in a nontoxic amount is able to treat infections of the lung caused by bacteria or viruses.

\section{CONCLUSION}

In this editorial, we summarized the unique properties of chlorine dioxide, which make it an ideal and nonspecific antimicrobial agent at concentrations harmless to humans, and we reviewed previous research on preventing viral infections with gaseous $\mathrm{ClO}_{2}$. Based on this background, we suggested some novel hypothetical methods using chlorine dioxide to disinfect rooms, prevent human infection, and slow down viral spread. These are nonspecific methods, which could be used against any newfound virus as a first line of protection until effective specific countermeasures are developed.

Conflict of interest: Zoltán Noszticzius, Maria Wittmann and Kristóf Kály-Kullai are co-inventors of the European patent 2069232 "Permeation method and apparatus for preparing fluids containing high purity chlorine dioxide". Zoltán Noszticzius is a founder and owner of the Solumium Ltd (a company producing chlorine-dioxide), while Kristóf Kály-Kullai is its payed employee. 


\section{REFERENCES}

1. Bastacky J, Lee CY, Goerke J, Koushafar H, Yager D, Kenaga L, et al. Alveolar lining layer is thin and continuous: low-temperature scanning electron microscopy of rat lung. J Appl Physiol 1995; 79(5): 1615-28, https://doi.org/10.1152/jappl.1995.79.5.1615.

2. Benarde MA, Snow WB, Oliveri VP, Davidson B. Kinetics and mechanism of bacterial disinfection by chlorine dioxide. Appl Microbiol 1967; 15(2): 257-65.

3. Cantin AM, North SL, Hubbard RC, Crystal RG. Normal alveolar epithelial lining fluid contains high levels of glutathione. J Appl Physiol 1987; 63(1): 152-7, https://doi.org/10.1152/jappl.1987.63.1.152.

4. Cao Z, Zhang Q, Lu X, Pfeiffer D, Jia Z, Song H, et al. Estimating the effective reproduction number of the 2019-nCoV in China. Available online at http.medxriv.org; Jan. 29; 2020; https://doi.org/10.1101/2020.01.27. 20018952.

5. Cross CE, van der Vliet A, O'Neill CA, Louie S, Halliwell B. Oxidants, antioxidants, and respiratory tract lining fluids. Environ Health Perspect 1994; 102(Suppl. 10): 185-91, https://doi.org/10.1289/ehp.94102s10185.

6. EPA Guidance Manual for Compliance with the Filtration and Disinfection Requirements for Public Water Sources (AWWA; 1991). Table C-9: CT values for inactivation of viruses by chlorine dioxide. Available at http://www.opssys.com/InstantKB/article.aspx?id=14495.

7. Forman HJ, Zhang H, Rinna A. Glutathione: overview of its protective roles, measurement, and biosynthesis. Mol Aspects Med 2009; 30(1-2): 1-12, https://doi.org/10.1016/j.mam.2008.08.006.

8. Hauchman FS, Noss CI, Olivieri VP. Chlorine dioxide reactivity with nucleic acids. Water Res 1986; 20(3): 357-61, https://doi.org/10.1016/0043-1354(86)90083-7.

9. https://www.britannica.com/science/coronavirus-virus-group.

10. Hui DS, Azhar EI, Madani TA, Ntoumi F, Kock R, Dar O, et al. The continuing 2019-nCoV epidemic threat of novel coronaviruses to global health - The latest 2019 novel coronavirus outbreak in Wuhan, China. Int J Infect Dis 2020; 91: 264-6, https://doi.org/10.1016/j.ijid.2020.01.009.

11. Ishi G. Solubility of chlorine dioxide. Chem Eng Japan 1958; 22(3): 153-4, https://doi.org/10.1252/ kakoronbunshu1953.22.153.

12. Ison A, Odeh IN, Margerum DW. Kinetics and mechanisms of chlorine dioxide and chlorite oxidations of cysteine and glutathione. Inorg Chem 2006; 45: 8768-75, https://doi.org/10.1021/ic0609554.

13. Knudsen L, Ochs M. The micromechanics of lung alveoli: structure and function of surfactant and tissue components. Review Histochem Cell Biol 2018; 150: 661-76, https://doi.org/10.1007/s00418-018-1747-9.

14. Koren E. A suggestion. Personal information; 2020.

15. Lubbers JR, Chauan SR, Bianchine JR. Controlled clinical evaluations of chlorine dioxide, chlorite and chlorate in man. Environ Health Perspect 1982; 46: 57-62, https://doi.org/10.1289/ehp.824657.

16. Morino H, Fukuda T, Miura T, Lee C, Shibata T, Sanekata T. Inactivation of feline calicivirus, a Norovirus surrogate, by chlorine dioxide gas. Biocontrol Sci 2009; 14: 147-53, https://doi.org/10.4265/bio.14.147.

17. Napolitano MJ, Green BJ, Nicoson JS, Margerum DW. Chlorine dioxide oxidations of tyrosine, N-acetyltyrosine, and Dopa. Chem Res Toxicol 2005; 18: 501-8, https://doi.org/10.1021/tx049697i.

18. Napolitano MJ, Stewart DJ, Margerum DW. Chlorine dioxide oxidation of guanosine $5^{\prime}$-monophosphate. Chem Res Toxicol 2006; 19: 1451-8, https://doi.org/10.1021/tx060124a.

19. Noss CI, Hauchman FS, Olivieri VP. Chlorine dioxide reactivity with proteins. Water Res. 1986; 20(3): 351-6, https://doi.org/10.1016/0043-1354(86)90083-7.

20. Noszticzius Z, Wittmann M, Kály-Kullai K, Beregvári Z, Kiss I, Rosivall L, et al. Chlorine dioxide is a sizeselective antimicrobial agent. PloS One 2013; 8(11): e79157, https://doi.org/10.1371/journal.pone.0079157. 
21. Ogata N. Chlorine dioxide gas for use in treating respiratory virus infection. European Patent Specification EP 1955719 B1. Priority to JP 2005342503; 2005.

22. Ogata N. Denaturation of protein by chlorine dioxide: oxidative modification of tryptophane and tyrosine residues. Biochemistry 2007; 46: 4898-911, https://doi.org/10.1021/bi061827u.

23. Ogata N. Inactivation of influenza virus haemagglutinin by chlorine dioxide: oxidation of the conserved tryptophan 153 residue in the receptor-binding site. J Gen Virol 2012; 93: 2558-63, https://doi.org/10.1099/ vir.0.044263-0.

24. Ogata N, Shibata T. Effect of chlorine dioxide gas of extremely low concentration on absenteeism of schoolchildren. Int J Med Med Sci 2009; 1(7): 288-9.

25. Ogata N, Shibata T. Protective effect of low-concentration chlorine dioxide gas against influenza A virus infection. J Gen Virol 2008; 89: 60-7, https://doi.org/10.1099/vir.0.83393-0.

26. Satomura K, Kitamura T, Kawamura T, Shimbo T, Watanabe M, Kamei M, et al. Great cold investigators: prevention of upper respiratory tract infections by gargling. A randomized trial. Am J PrevMed 2005; 29: 302-7, https://doi.org/10.1016/j.amepre.2005.06.013.

27. Stewart DJ, Napolitano MJ, Bakhmutova-Albert EV, Margerum DW. Kinetics and mechanisms of chlorine dioxide oxidation of tryptophan. Inorg Chem 2008; 47: 1639-47, https://doi.org/10.1021/ic701761p.

28. Tan H, Wheeler BW, Wei C. Reaction of chlorine dioxide with amino acids and peptides: Kinetics and mutagenicity studies. Mutat Res 1987; 188(4): 259-66, https://doi.org/10.1016/0165-1218(87)90002-4.

29. Tao Y, Queen K, Paden CR, Zhang J, Li Y, Uehara A, et al. Severe acute respiratory syndrome coronavirus 2 isolate 2019-nCoV/USA-IL1/2020, complete genome. NCBI GenBank; 2020. Available at https://www.ncbi.nlm. nih.gov/nucleotide/MN988713.1?report=genbank\&log $\$=$ nuclalign\&blast_rank=1\&RID=304U21XH016.

30. US Occupational Safety and Health Administration. Determination of chlorine dioxide in workplace atmospheres; 1991. Available at https://www.osha.gov/dts/sltc/methods/inorganic/id202/id202.html.

31. www.solumium.com.

32. Zuurbier M, Hoek G, van den Hazel P, Brunekreef B. Minute ventilation of cyclists, car and bus passengers: an experimental study. Environ Health 2009; 8: 48, https://doi.org/10.1186/1476-069X-8-48.

Open Access statement. This is an open-access article distributed under the terms of the Creative Commons Attribution 4.0 International License (https://creativecommons.org/licenses/by/4.0/),which permits unrestricted use, distribution, and reproduction in any medium, provided the original author and source are credited, a link to the CC License is provided, and changes - if any - are indicated. (SID_1) 